\title{
Letters to India
}

\section{A young Jewish woman immersed in the musical life of post-war London corresponds with an English soldier in India}

\author{
Clive Tolley
}

DOI: https://doi.org/10.30752/nj.107706

Aвstract - I write as a non-Jew about the brief correspondence sent to my father, shortly after the Second World War, from a gifted, young Jewish violinist, and briefly outline the background story-arc of her family's aliyah, from the Pale a couple of generations earlier to her settlement in the new state of Israel. Her story is not bound up with the Holocaust, nor (as far as we know) did she experience antisemitism: but this essay attempts to highlight the majesty and sparkle of a moment in the mundane life of a Jewish woman, and its brief impact on a gentile. The focus is on her musical remarks about some of the leading performers of the day. I also outline some of the ways I secured source materials for this primarily biographical sketch, but this article is presented more as a 'memoire' than an academic study. It is offered in honour and memory of a Jewish lady whom, alas, I was a little too late to meet myself, and to celebrate my father's hundredth birthday in May $202 \mathrm{I}$.

\section{A dusty old bag reveals its secrets}

Shortly before Christmas 20I7, as I was about to depart for my home on the other side of England after a brief visit, my widowed, ninety-six-year-old father, Clement Gordon Tolley, handed me an old, dusty bag, tied with a ragged shoe-lace. 'Have a read of these when you get home,' he said. 'You might find them interesting.' He saw me on my way without saying anything more.

Several hours later, the bag revealed its contents. It was a clutch of papers - mostly hand-written letters, but with other items like job details and applications. All of it dated from before I 950, the year my parents married. As I delved into the jumble of correspondence, the years seemed to fall away like the dust from the scrappy bag that had held it in confinement for so long, and I saw my father as a young man, serving in the army in the war and then posted to India in 19456 , before his return home and his attempts to establish a career for himself. Some of it brought a smile to my face: the reply from someone he claimed to have known in Belgium before the war (my grandfather worked for the War Graves Commission near Ypres and my father grew up there), from whom he had clearly sought a job, but who politely apologised for having no recollection of my father at all!

The field my father really wanted to work in was violins. My grandfather was quite a skilled violinist, and his wife a gifted amateur piano player. My father inherited the musical interest, and was interested not merely in playing, but also in making instruments. Several of the applications in the dusty bag were to instrument dealers and manufacturers.

Apart from a job, one of my father's chief concerns at this point - as it must have been for many ex-servicemen - was to find a wife. The largest collection of letters was, in fact, from his girlfriend during the war; it was interesting to read the story from start to 


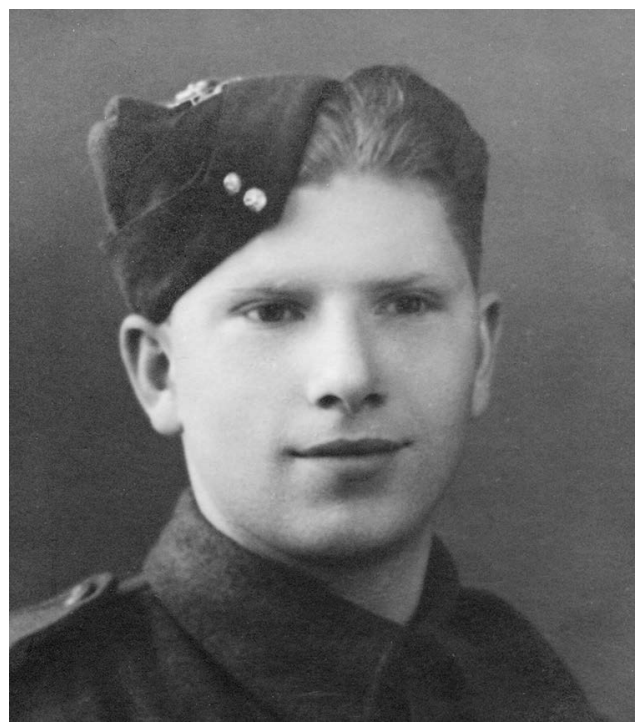

Gordon Tolley when joining the army.

finish - and to see the rather different light it shed on the relationship from what he had told me himself - but that does not concern us here. After the end of the war in Europe in May I 945, my father found himself posted out to India; he stayed almost the whole time in the infamous Doolally (Deolali) transit camp, where a lengthy sojourn was reputedly so mind-numbingly tedious that the phrase 'go doolally' derives from it.

We may imagine that the mental stress of being sent out to the Far East - for that was where the British troops were headed, to fight the Japanese in Burma and beyond - must have been relieved (though no doubt with some horror at the means by which that relief had been effected) with the capitulation of Japan following the atomic bombs of Hiroshima and Nagasaki in August I945, but this was followed by an increasing ennui among troops who had been called up explicitly 'for the duration' of the war, but who, with the war now brought to a sudden halt, were left to wonder when they might finally see home again once the slow wheels of bureaucracy had managed to catch up with the situation and they could be demobbed. The conscripted troops were not, to my knowledge, used against the rising tides of Indian nationalism (a movement of which my father seems to have been blissfully ignorant).

My father, in any case, never mentioned any mental problems with staying there (indeed, he in fact manipulated the system to ensure he remained in the transit camp rather than being posted on). Instead, no doubt like many others, he was devising plans for his return home. He decided, it seems, to try to kill two birds with one stone by resorting to an unusual method, in these days long before social media had been dreamt of, of setting things in motion both career-wise and marriage-wise. The cunning plan he executed was to place an advertisement in the March I 946 issue of the main popular journal aimed at serious classical stringed-instrument players, The Strad: 'Amateur violinist serving with H.M. Forces in India would like to correspond with anyone interested in playing and making of instruments played with the bow. Age 24. Replies guaranteed. Box I749 c/o The Strad office, 2, Duncan Terrace, London, N.r.' 1 Although this sounds neutral, the fact that all the replies he kept were from young women rather lays bare his intentions, I think. A little sneaky, perhaps - but not dishonourable; he was clearly hoping to form a relationship with someone he shared a musical passion with, while also hoping to make contacts that would ease his way into the instrument industry.

1 My father no longer had the issue. The

Strad magazine did not reply to my request, and I could not track down a copy in any accessible libraries. I decided to advertise on The Pegbox, a forum for violin-makers, in case anyone had a copy - though I thought it a long shot. I thank Jacob Saunders for his almost immediate reply, and for scanning the relevant sections of the issue for me. 
Entered as second-class matter, March 17th, 1925, at the Post Office at Providence, R.I., U.S.A., under the Act of March 3rd, 1879
Sec. 397 P. L. \& R.).
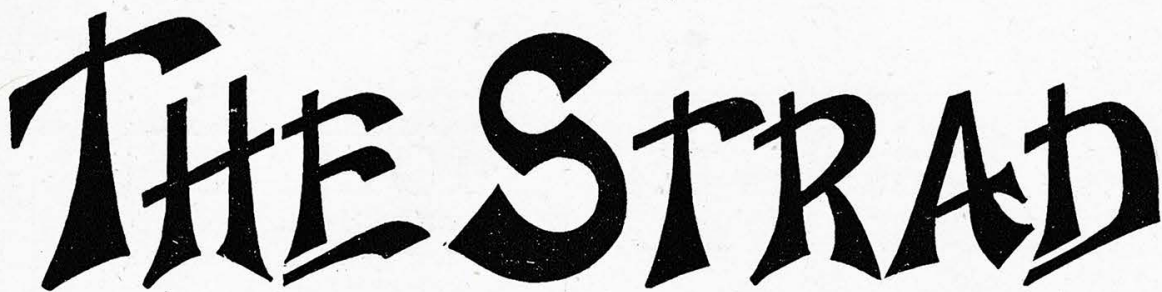

$\mathfrak{A}$ Allontbly $\mathfrak{J}$ ournal far 1 Professiomals and Amateurs of all tringed Jnstruments 羽laped with the 积ow

Vol. LVI No. $671 \quad$ MARCH $1946 \quad$ PRICE SIXPENCE

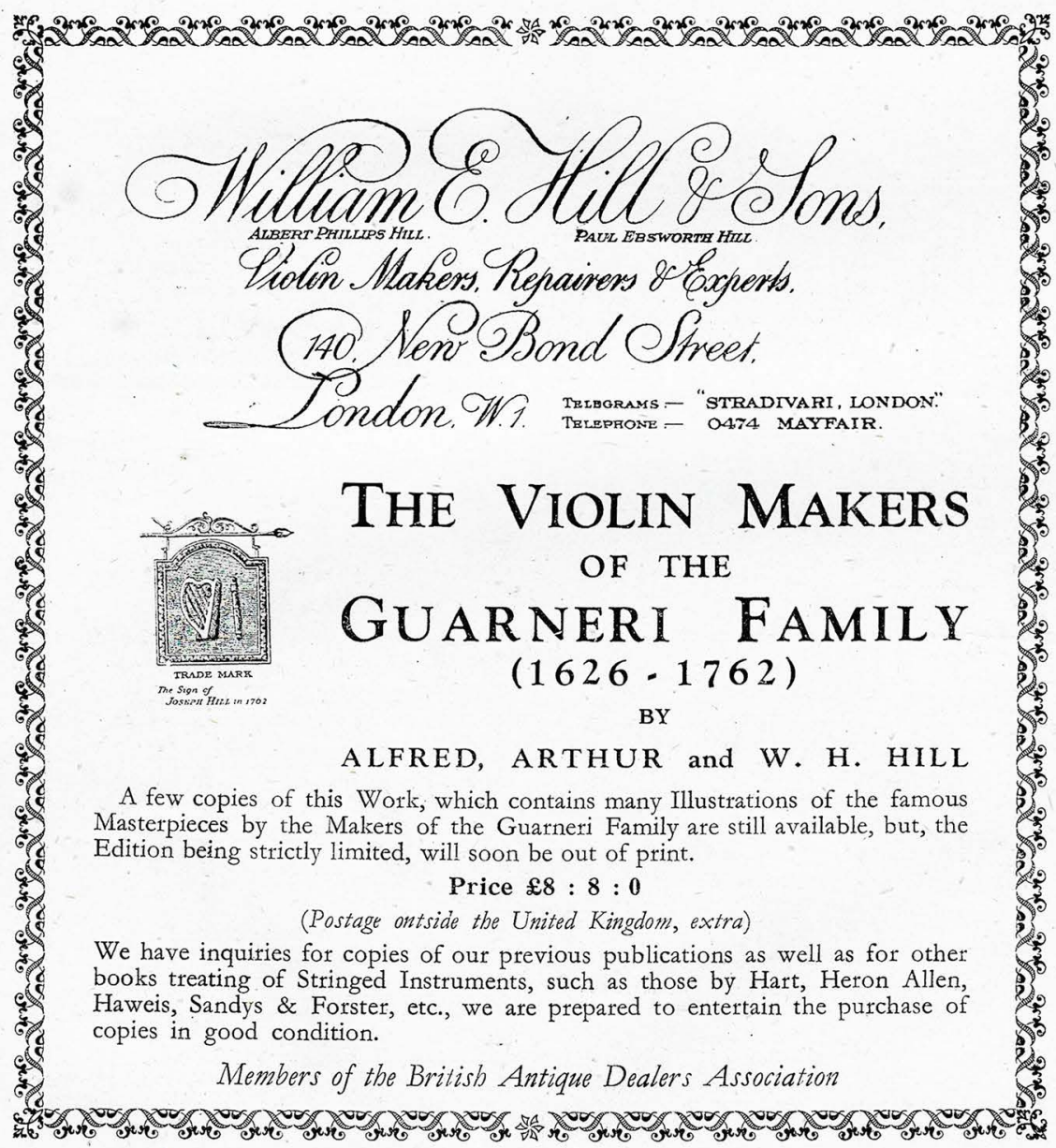

The cover of the March 1946 issue of The Strad. 


\section{MISCELLANEOUS. ONE SHILLING PER LINE. Minimum $3 / 0$}

For the use of Box Number an extra charge of $6 \mathrm{~d}$ is made.

Closing date for press 18 th. Advts. to be addressed to the MANAGER,

2, Duncan Terrace, London, N.I. D IAGRAMS (Violin only), Guarneri, Gasparo or Mag. $D_{\text {gini, each } 1 / 3 \text {, post free, also other Honeyman publi. }}^{\text {Lathe }}$ cations (Copyright). All printed and published in Scot-
land by L. Honeyman, "Cremona," Newport, Dundee,
Scotland W ANTED: Violins, 'Cellos and Violas by the finest English, Italian and French makers. Good price "Crered for genume instruments having certificates.
"Cremona," c/o The Strad Office, 2, Duncan Terrace, London, N.1. AMIBR OIL VARNISH is still the BEST $\mathrm{H}_{\text {after }} 40$ years. $6 \%$ per bottle. Pamplilet of colours and directions for stamp. J. E. Harris, 88, Bewick Road, Gateshead-on-Tyne, $\mathrm{C}_{0}$. Durham, England

$\mathrm{R}_{\mathrm{R}}^{\mathrm{OBERT}}$ ALTON, Violin Expert, 32, "Rock Lane, E. $\mathrm{R}_{\text {Rock Ferry, Birkenhead. Author of "Violin Making }}$
and Repairing," etc. Maker's tools and materials. First and Repairing," etc. Maker's tools and ma

THE Forrester semi-wood superfine hand-made flexible $\mathrm{T}_{\text {violin }}^{\mathrm{HE} \text { purfling; three grades, }} .060, .050, .040$, slats 11in. $x 1 \frac{1}{2}$ in. equivalent for purfling two or more violins. One slat $5 \%$, five $£ 1$. Viola purfling, 13 in. $x 1$ inin. $x$ .065. One slat 6/., four \&1. Alexander Forrester, Violin Maker, Bellona Terrace, Fauldhouse, Scotland. M ONOMARK Service. Permanent London Address. $M$ Letters redirected. Confidential. $5 /$ - p.a. Royal
patronage. Write Monomark BM/MONO7C, W.C.1. patronage. Write Monomark BM/MONO C, W.C.1. $\mathrm{R}_{\text {ments }}^{\text {EPAIRS, high-class testorations and tonal improve- }}$ sale. H. S. Hales, 120, Paynes Lane, Coventry.

A MATEUR collector wants to buy violins and bows The BRAMSON MUSIC SERVICE for Orchestrations, B Compositions, Films, Copying, etc. Prompt service. R. Bramson Music Service, Oxford House, 9-15, Oxford Street, London, W.1. (GER 7067). 6 for violin $W_{\text {music or full size violin outhit. Roselea, } 5 \text {, Ash }}^{\text {ILL exchange eductional course value } £ 6 \text { for violin }}$ Road, Four Marks, Alton, Hants.

A MATEUR violinist serring with H.MI. Forces in in playing and making of instruments played with the bow. Age 24. Replies guaranteed. Box $1749, \mathrm{c} / \mathrm{o}$ Tite SEEN any time, genuine old violind an, dealers' prices. $\mathrm{S}$ Many known makers. Joe, 16, Bayliss Road, Water-

Foo, S.E.1. 5 old Cellos, Want fitting up. Any

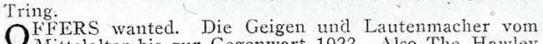
O Mittelalter bis zur Gegenwart 1922. Also The Hawley Collection of Violins (brochure No. 1619) Lyon and Healy, 1904. T. Toomey, 53, Park Crescent, Enfield. W ANTED: Violin for its tone value. Box 1750, c/o $\mathrm{V}_{3}^{\text {IOLIN for sale: Juke model, good tone, £5. Also }}$ Trave 1396 .

grove 1396 ; CELCO John Betts 1795 , in wooden box. Seen by 'C ELLO by John Betts 1795, in wooden box. Seen by Enfield. HOSE HIL viola, $1511 / 15$ inch, dated 1770 , with $J_{\text {case, rubber bag, two Hill bows and Hill's guarantee. }}$ Phone Elstree 1 Terrace, London,

J. J. G G ILERT violins for sale, finished and uninetter to Miss E. J. V. Howard, 66, Burlington Lane, Chiswick,

'C ELLO by Jacobus Horil, Tecchler copy, Hill's case, 2 bows, bow case. 260 inclusive. Box $1752, \mathrm{c} / 0$ case, 2 bows, bow case. 260 inclusive. Box B ASS wanted. State fullest particulars, condition,
price, etc. 34, Washington Avenue, Eastrille, Bristol, 5 .

\section{VIOLINISTS and all Players of Stringed Instruments}

\section{would be well repaid by a visit or by sending for a} Catalogue, for I confdently state that no other Dealer in the provinces can offer such a wide choice of instruments which include such gems of the old Italian makers Camillius Camilli, Dalaglio of Mantua, Joseph Marconcini, Lorenzo Guadagnini, Guiseppe Pedrazzini, Michele Deconet, Gio. Baptistta Rogeri. All with Hill or Hart Certificates.

$$
\begin{gathered}
\text { Special March Offers } \\
\text { VIOLINS }
\end{gathered}
$$

To Teachers, I am offering the following makers at the bargain price of $£ 20$ each. Very suitable for adAndrew Hume, London dated 1930; James Gilchrist, Glasgow, dated 1930; Pierre Jacquot, Nancy, 1878 .

Special Bargain

ean Baptiste Vuillaume, Paris, Hill' $\begin{array}{lllll}\text { Cert. Perfect condition. Strad model, } & & & \\ \text { wonderful tone } \ldots & \ldots & \ldots & \end{array}$

VIOLAS

Id Italian Viola by Gio. and Francesco

Grancini, dated 1694. A very fine

$£ 100 \quad 0 \quad 0$ William Forster, Jun., London, dated 1810 . Splendid example, in perfect condition. $15 \hbar^{*} £ 50 \quad 0 \quad 0$ Old Italian Cello of the Brescian School, $\begin{array}{lllllllll}\text { about } 1750 & \ldots & \ldots & \ldots & \ldots & \$ 35 & 0 & 0\end{array}$ Thomas Kennedy, Ioncion, about 1820.

A fine example in splendid conditio

\section{PÖWELL̈ $\approx \ldots 35$ \\ 64, Vicarage Road, Smethwick 41}

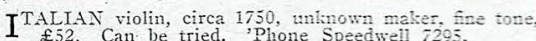
$\mathrm{B}$ OOKS for sale. Hart, Violin Makers. Heron-Allen, Violin Making Hill, The Guerneri Family Goo Duncan Terrace, London, N.1. $\mathrm{S}_{\text {good condition. Box } 1754 \text {, c/o The Strad Office, }}$

LD Hill "Cello and bow for sale. Perfect condition. Box 1755 , c/0 The Strad Office, 2, Duncan Terrace, $\mathrm{SAVE}$ money. Private collection of fine old violins fo $\mathrm{S}$ sale at pounds less than dealers prices. Hill's ce Terrace, London, N.1. C HOICE collection of chamber music for sale. New condition. About 200 sonatas, etc., violin and pian Haydn Quartets, etc. 18, Priory Crescent, Wembley. Middx.

$\mathrm{P}^{\text {ALM }}$ Court music library for sale, in good new conPdition. 136 musical comedy selections. 79 suites, 165 entractes and intermezzi, overtures, marches, waltzes

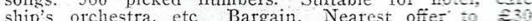
Musical Diretcor, Breck Mount, 2, St Hila B-om, Wallasey, Cheshire. THE STRAD, three years, 1943

Telves, Lynton, Horam, Sussex. Fitalian and French violins. C. A. Hoiss 45 , Q Green Street, High Wycombe, Bucks. _.

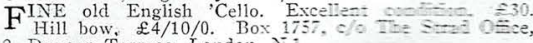
2, Duncan Terrace, London, Nil. piano, piano trios, quartets, chatober masio and nusic
for full orchestra. Send $6 d$. for fuil caralsose to B.T/VIOL, London, W.C.1.

RICHARD DUKE violin for sale, Withers (teioster $\mathrm{R}$ Square) opinion. Bvoellent tone, Withers thesester (Contimed on page iii of cover) 


\section{The Jewish connection}

There were a few replies preserved in the bag, but just one respondent continued the letter exchange for a considerable length of time. She was a Jewish woman named Doris Bresh, who lived in a poor district of east London; she was twenty years old at the time of writing (as she spells out in her first letter). The relationship that developed was one of friendship; Doris was effusive in her comments on the classical music of the time, which was the focus too of my father's interest.

I was struck, as soon as I started reading Doris's letters, by her sharp, perceptive intelligence, and the endearing balance between enthusiastic youthful exuberance - even sometimes a cheekiness (a gentle sort of chutzpab, we might say) - and the inchoate poise of maturity. It is these qualities that

\section{Dear - ? -}

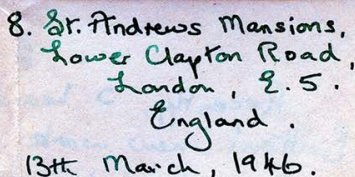

$I$ have just noriced your advertisement in this monthis "Strad". "I am 20 years old, and 9 too am an amateur vidinist. My two cousins have ist returned from service in India, and, as a result, do nit need my services as letter-writercam-describer-of-concerts, in which capacity 9 have leen wirting to tteon for the past few years. Would you like a veference from Hem? 9 have vidin lessons from a man who has just lept the Landin Plitharmonic Orcherra - he used to le sub-leader. He now plays witt various London orehertias and quarters, efc. Igo to concerts about once a week and, when 9 san get in, to opera and vallet. shine out in her observations, in particular her many musical appraisals, notably of some of the leading performers of the time, and that above all make what she wrote fascinating to a wider audience. I will come on to her performance appraisals presently; first, I would like to give a picture of the woman who wrote them, based on the correspondence in general.

In her first letter, of I $_{3}$ March I 946, Doris introduces herself as being an amateur violinist too, like my father, and as now being freed from her role, exercised over the last few years, as 'letter-writer-cum-describer of concerts' to her two cousins, who had recently returned from service in India. ${ }^{2}$ She writes that she has violin lessons from the recently retired sub-leader of the London Philharmonic Orchestra. She goes to concerts, and, when she can get in, to ballet and opera every week. She writes that 'Recently, I heard Peter Grimes, Britten's new work. I liked it very much indeed.' She is clearly openminded, for the time, as this is a challenging work - and she is, I think, fishing, to see what response that might evoke; my father's tastes, however, never extended to anything later than Brahms, excepting the popular songsheet songs of the I930s and I940s, which he collected in abundance. ${ }^{3}$ She adds that 'If you are interested, I could tell you bits about the things I hear as I used to tell my cousins, and perhaps send you the programmes.'This

2 We have not been able to identify these cousins, but we are fairly certain they were on Doris's mother's side.

3 As his letters are lost, we cannot say what his comments on Peter Grimes may have been, but he is unlikely, in any case, to have listened to it (even if it were possible in India); his few comments made at other times on Britten were not antagonistic, but neither did they show any particular interest in engaging with his music. 
set off a correspondence focused on comments about musical performance, both her own and that of the players whose concerts she attended.

Doris wonders if my father is able to practise the violin out in India (in fact, he was not able to: GT); she says she finds it difficult to fit in the two hours a day she needs to do. She relates that she is working for the export department of a musical instrumentmaking business. She rounds off with a diffident statement: 'No doubt you will get many replies to your advertisement, so if you do not wish to write to me, do not bother to write and say so. I shall understand.'

My father replied, of course, relating a good deal about himself and his musical background, and Doris in turn sent off her own twelve-page response. She writes that 'I seem to know you quite well already - just from your letter. It's funny (funny peculiar - not funny ha-ha!) that when people feel the same way about music you get to know them quickly, whereas some people who just don't understand, you can know for years, and still not really become close friends.' She describes herself and her background - but notably nowhere says that she is Jewish. 'I told you I was 20 (last February); my height is $5 \mathrm{ft} 5$ ins., I have a fair complexion, chestnut brown hair - very wavy and won't keep tidy, and I have brown eyes.' She envies my father's musical family, in particular his violinist father; her own father, she reveals, was not supportive of her musical endeavours. It was her mother, who was keen on music, who struggled, through their poverty, to get her music lessons.

She worked as a secretary after leaving school, and was then called up to work in the Cabinet Office, from which she was released after VJ day (August I 945). She then gained a position at the musical company of Rose, Morris \& Co., in Ironmonger Row, London,

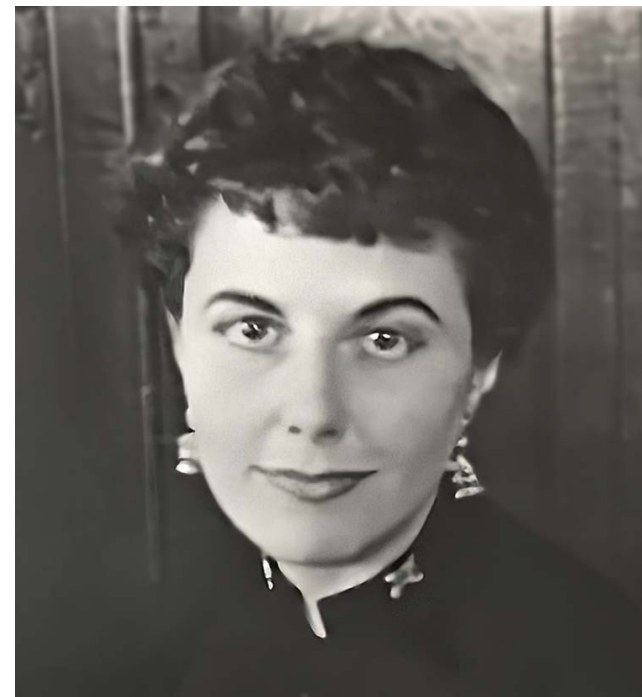

Doris as a young woman.

where, she writes, she is very happy in the family-like atmosphere. Despite a break in her music lessons, she became seriously interested around the age of I 4 and started going to concerts. She focused her attention on the London Philharmonic Orchestra, befriending many of its members; one of them, the double-bass player Gerald Brooks, managed to secure her an instrument, a Havemann violin reputedly from around I700 (it must have been rather later than this, in fact), which she describes as wonderful. Brooks also introduced her to her teacher, Oscar Rosen, who had played with the Philharmonic for a few years from I942. She has been studying with him for eight months, and is just finishing Joachim's second book (Joachim was the great violinist for whom Brahms wrote many pieces). Rosen and his family have 'adopted' her, and treat her lovingly; she has a lesson, then stays for the evening with them. She is now his only pupil, as he is doing it as a favour to Brooks, but enjoys it. She writes that some people ask, "Why are you learning?" It's impossible to explain that I must learn because I want to - that I would do anything to learn - and that is all I want.' 
She reckons it is now too late for her to think of playing professionally, but she is happy to just play at all. She encourages him to apply to study violin-making at the College of Music. 'You say "lucky me" for being in the musical world. I think so too, but I did want so badly to be in it, and I still can't believe my luck. But you! How I envy your musical father! It should be easier for you, anyway.' She says she has not listened to many string quartets, but likes the music, especially (as he had suggested) Haydn and Mozart. ${ }^{4}$ But she begs to differ in terms of taste, as her preference is for orchestral music. 'If I had your flair for poetry, I would write a sonnet to the orchestra. ${ }^{5}$

She asks if he has read Oscar Wilde's The Picture of Dorian Grey; she thinks it has some beautiful prose, and quotes a section:

At another time, he devoted himself entirely to music ... He used to give curious concerts in which mad gypsies tore wild music from little zithers, or grave yellow-shawled Tunisians plucked at the strained strings of monstrous lutes, while grinning negroes beat monstrously upon copper drums, and, crouching upon scarlet mats, slim turbaned Indians blew through

4 My father has always favoured the music, in particular the chamber music repertoire, of Haydn, Mozart and Brahms, often to the exclusion of anything else.

5 He had sent her a poem, which may well have struck a chord as she had literary interests herself (as she states in the letters; she had, for example, contributed pieces to her school magazine), which continued through her life (DH-G); yet my father's literary aspirations did not in fact extend very far - he claims, for example, to have only ever read one novel, Daphne du Maurier's Rebecca, which he worked through on the long passage to or from India. long pipes of reed or brass, and charmed, or feigned to charm, great hooded snakes and horrible horned adders. The harsh intervals and shrill discords of barbaric music stirred him at times when Schubert's grace and Chopin's beautiful sorrows, and the mighty harmonies of Beethoven himself, fell unheeded upon his ear.

\section{'Isn't it lovely!' she asks. ${ }^{6}$}

She did not hear back for a month, but decided to send another letter at the end of May. She was keen to send some concert programmes with her notes about the performances. She says there have been some lovely concerts lately - 'not like the war days, when the LPO gave about one a month, and you looked forward to that one all the month before it finally arrived. Next month (June) there are concerts with Szigeti, Beecham and Menuhin which I hope to hear. Lovely!!'7 She then goes on to ask,

6 We may, I think, appreciate the Romantic qualities Doris saw in the passage, though a modern reader would need a certain 'suspension of disbelief': she was writing, of course, in days before the rise of any consciousness of the need to avoid the sort of denigratory racial stereotyping Wilde someone who, ironically, himself suffered greatly as a result of prejudice, in his case of homophobia - engages in here.

7 These are leading names in the music world, of course. The Jewish violinist Yehudi Menuhin (1916-99), Americanborn but spending most of his life in Britain, played to the inmates of the liberated concentration camps at the end of the war, and was not only a great violinist in his own right, but also worked strenuously for reconciliation and reconstruction after the war, as well as for the fulfilment of musical aspiration among youngsters, for example by founding the Yehudi Menuhin School in England in 1962, and the Yehudi Menuhin International Competition for Young Violinists in 1983. 
Have you ever heard Ginette Neveu? She is a French violinist of about 26 , and has recently been playing in this country. I have been to several of her concerts, including the recital she gave with her brother (advertisement enclosed). She is absolutely SUPERB! (Yes, she deserves capital letters!) She has a great deal of force and fire in her playing - not mere emotional fire (though she has plenty of that) but an almost masculine intensity and drive. You can't imagine how wonderfully she plays the Brahms.

She writes that, along with some friends, she has just bought the recording of Neveu playing the Sibelius Violin Concerto, conducted by Walter Süsskind with the Philharmonia Orchestra, as a birthday gift for another friend: 8

This is the best recording I have ever heard, and that's saying something. In places, her tone is so deep that it sounds like a 'cello, not a violin. You really must hear her some time. She is marvellous. Of course,

8 The recording can now be found on YouTube, and although it does not, of course, match up to modern recording standards, a good deal of the power of her playing that Doris comments on may be discerned. The encounter with the Neveu siblings is particularly poignant: a few short years after the concert, on 27 October I949, they were both killed when their flight to New York was diverted to the Azores and crashed on a mountain side. Ginette's precious Stradivari violin, which she was said to be clutching (according to some report my father read at the time), perished with her. It was widely recognised that the music world had lost one of its greatest young violin talents when Ginette perished. The loss of Ginette Neveu was something my father often lamented when I began learning the violin.
Menuhin's tone is really sweeter, but I think that I prefer Ginette to anybody else. I have been lucky enough to get in to talk to her a couple of times - she only speaks French. She is dark, and masculine-looking, but I think very attractive. Her violin is a Strad. $\mathrm{Oh}$ ! I do wish you could come and hear our recording of the Sibelius. My friend is having a party on Sunday and is going to play some records - with the Sibelius as the 'piece de resistance'.

She then notes how her teacher, Oscar, has returned from a lovely trip to Switzerland; at one concert, they had Furtwängler and Richard Strauss in the audience. ${ }^{9}$ She loves Strauss's Rosenkavalier waltzes, and Till Eulenspiegel.

She had asked the manager of the company where she worked about the possibility of finding my father a job, but had been told that they would not be resuming violin-making at all, but rather concentrating on guitars and mandolins, but that he invited my father to go along to see him if he wanted. She notes that, nonetheless, there are plenty of other companies engaging in violin-making, and is sure he will get something suitable; but the best idea would be for him to get some training and get a position with a firm that would allow him to train on the job. 'I'm sure it will all come right when you're back.'

She wrote again on 17 June, after receiving a letter from my father. He was due to

9 Both Furtwängler and Strauss came under criticism for their ostensible support of the Nazi regime; Furtwängler had conducted, and Strauss held some prestigious positions. Yet both had in fact tried to help Jews; in Strauss's case, this involved members of his own family. Soon after the war, Yehudi Menuhin went out of his way to play with Furtwängler to demonstrate his support. 
come back home on the next transport, and had been ill, and hence had not written. 'I'm glad you are in the next group to be sent home, and do hope it will be soon. It will be lovely to see you, and I, too, hope we shall be good friends.'

Owing to the damp and changeable weather, she was a little ill, and tucked up in bed.

Of course, I didn't help things by standing in the rain all yesterday afternoon trying to get a ticket to hear Lily Pons [a renowned operatic soprano] at the Albert [Royal Albert Hall]. I waited to see if any of my doormen-friends got any returned tickets, but my friends and I were unlucky. However, we did see Malcolm Sargent. On Wednesday, we are going to hear Szigeti play the Beethoven, and I shall be sending you a couple of programmes I've got for you. Next Sunday is Menuhin playing the Brahms (lovely!!) and the following week Mischa Elman playing the Beethoven and Tschaicowsky !!!! I shall be having a busy fortnight!!

She encourages him not to get too homesick - or she wouldn't send any more programmes! 'So just pretend you were at the concerts with me, and think about how lovely it was.'

She is glad to hear that he has a chance to work for Boosey \& Hawkes, a good firm that her own firm has dealings with.

The musical instrument trade is such fun. I have had a couple of offers to change my job recently - one was very good - I could have made my own terms - but I decided that I wouldn't change. I really do love my job - and everybody at R.M.'s is so friendly.

She then moves on to some political commentary:
I'm so glad that you think Casals is right about not playing here. I think he is doing a fine thing to do what he thinks is right. In spite of what people say about Art having nothing to do with Politics (which is true) he has made an effective gesture in support of his principles. As for Spain, I think the fascist regime there is a disgrace to the world and that it should be allowed to continue is as much a threat to future world peace as ever Hitler's regime was. I was glad to hear on the news this evening that the matter has been referred to the Security Council of UNO. How can people support fascism and theories of violence and hate? It is so unnecessary. How much easier it would be to run a world where the nations worked together without any suspicions, jealousies and rivalries. Is such a thing possible? I suppose we shall have to wait and see.

She goes on to describe the Victory Day parade in London a few weekends before:

There were parades and flags, and general hilarity. I began by thinking it was a great waste of time and money, but when I saw how all the people were enjoying themselves, in spite of absolute avalanches of rain in the afternoon - well, perhaps it wasn't such a waste of time after all. The aeroplanes which took part in the fly-past Whitehall, came past our window on the way there, so we had a private view to ourselves (out of the rain). That was all I saw of the parade! Some people though, stayed up all the previous night to get a good view, including some students, a man who took the bed he'd used in the air-raid shelter and camped on the pavement, and two sailors who slung hammocks between the trees (and stayed in them for the parade to get a good view!). On the Sunday, I went to 
Hampton Court, which I love, and in the evening, heard the New London Orchestra playing in the Orangery (I'm sending you the programme). It was lovely. Very old-fashioned and other-worldish. I adore places like Hampton Court which take you right back into other centuries, don't you. Have you read Eleanor Farjeon's 'Humming Bird'? That always has the same effect on me. I always feel eighteenth-century and 'I've been here before' when I read it - d'you know the feeling? And when I stop, and remember I'm here, in this all too modern twentieth century, I feel so out-of-place. I hope you understand - or do you think my sore throat is making me talk nonsense? But if you are feverish too, you will understand! Anyway, we must go to Hampton Court when you are home.

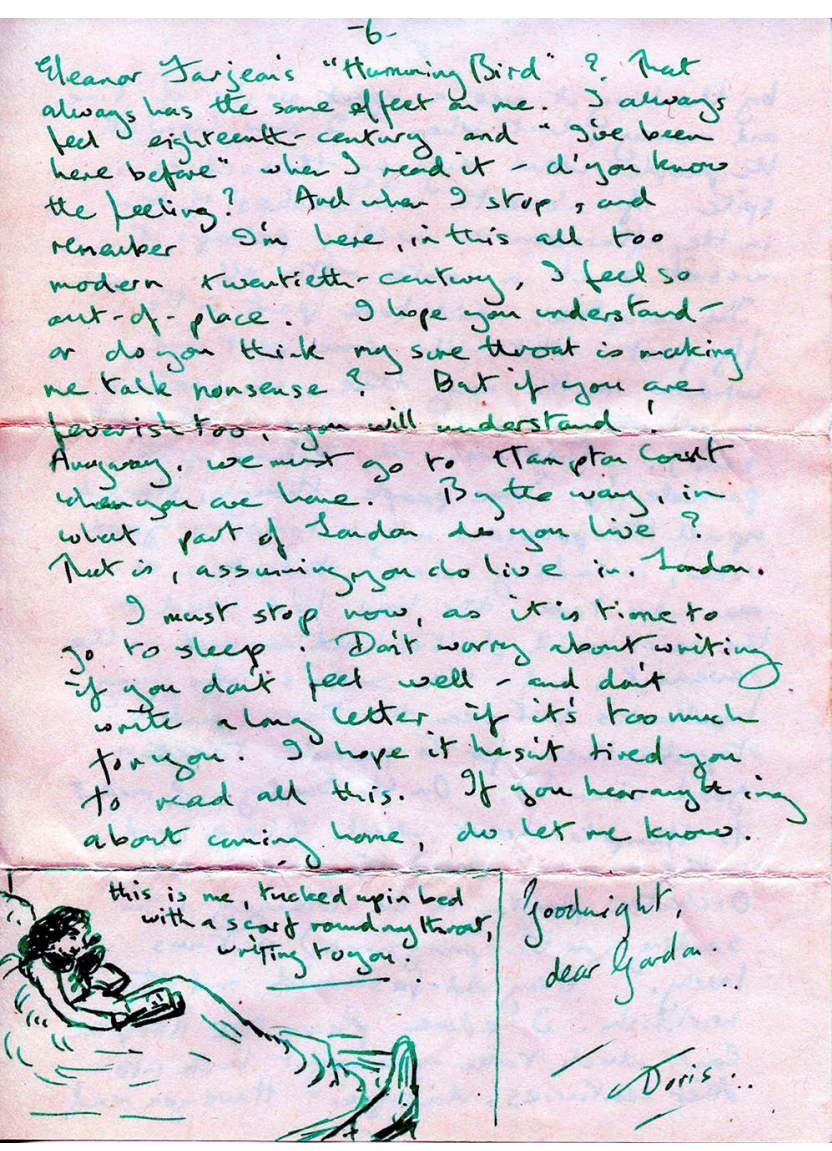

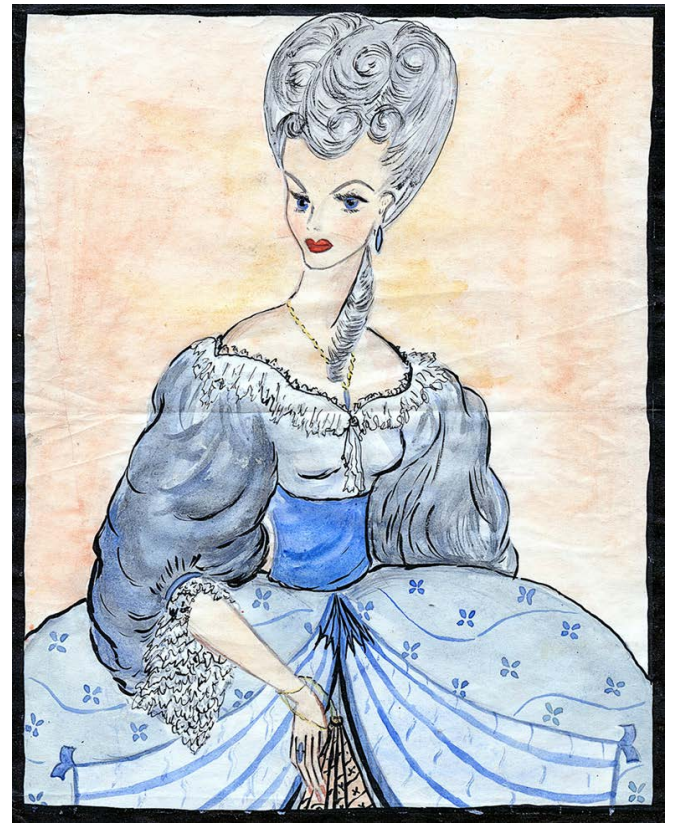

She rounds off with the wish, 'If you hear anything about coming home, do let me know. Goodnight, dear Gordon. Doris.'

It seems she did not receive any more letters; he had left India on the six-week passage home, and the two brief messages she sent were passed on to his parents' address in Peckham Rye, London.

\section{Concert programmes}

What is objectively most interesting in the correspondence are the concert programmes Doris sent, along with her comments. Rather than weighing matters down with biographies of the personages who appear, I will assume some knowledge of the classical music scene on the part of readers; I will merely note that the performers and conductors, almost without exception, make up a roll-call of all the most prominent and renowned exponents of classical music of the immediate post-war period. Doris's engagement with them, sometimes on a personal level, forms an important testimony of the period's musical life in the capital, and is quoted here verbatim. 


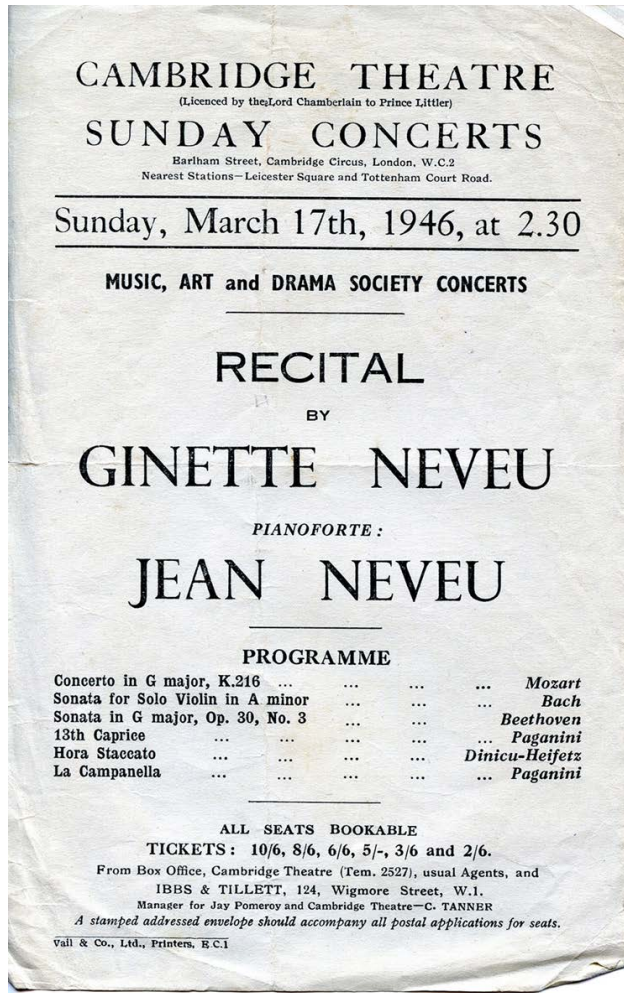

Cambridge Theatre, Cambridge Circus

Recital by Ginette Neveu with Jean Neveu

(pianoforte)

Mozart, Concerto G major K216

Bach, Sonata for solo violin A minor

Beethoven, Sonata G major, Op. 30, no. 3

Paganini, 13th Caprice

Dinicu-Heifetz, Hora staccato

Paganini, La Campanella

Sunday, 14 April

Royal Albert Hall

Harold Holt Sunday Concerts

London Symphony Orchestra,

leader George Stratton

Conductor: George Weldon,

Soloist: Bronislaw Huberman

Lovely concert. Huberman wonderful. I adore the Brahms. I love especially this theme from the ist movement (of the Brahms). I've just jotted it down, and hope you can read it.
Sunday, 21 April

Royal Albert Hall

Harold Holt Sunday Concerts

London Symphony Orchestra,

leader George Stratton

Conductor: Edric Cundell,

\section{Soloist: Bronislaw Huberman}

The orchestra weren't too good, and the Mozart was very 'heavy'. Huberman was wonderful, though. His bowing is absolutely superb, although he is getting old. Myself and 3 others managed to see him afterwards, and he autographed my programme. I tried

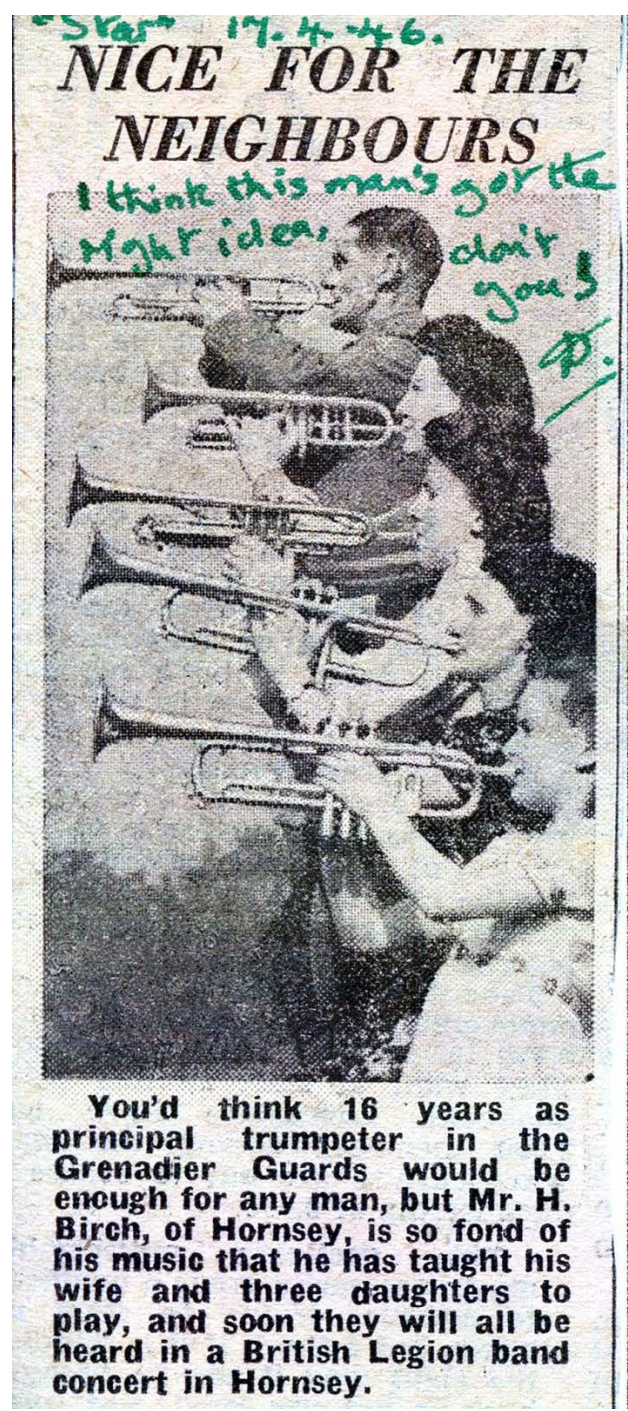

Doris's humour. 
to get him to autograph this for you, but he seemed to think I'd had my share! The Bach and Symphonie Espagnole are lovely - but I prefer last week's Brahms.

\section{Sunday, 28 April}

Royal Albert Hall

Beethoven Concert

London Symphony Orchestra,

leader George Stratton

Conductor: Karl Rankl, Soloists: Lamond, Alfredo Campoli

Egmont Overture, op. 84

Violin Concerto in D major, op. 61

Piano Concerto no. 5 in E flat major, op. 73

Leonora Overture, op. 72a

Lamond played badly, but I was told he was feeling very ill. He looked it. Campoli was technically brilliant, but he hasn't much emotional power. It was, at any rate, unusual to have 2 concertos in I programme.

\section{Sunday, 12 May}

\section{Cambridge Theatre}

Music, Art and Drama Society concerts

New London Orchestra, leader Max Salpeter

Nina Milkina

Conductor Alec Sherman

This was a lovely concert. Everything well played, especially 'The Swan' and 'Polovtsian Dances'. The Rach. Piano Concerto is magnificent and she played it very well. The Schubert - as usual - is very pleasant.

\section{Thursday, 23 May}

Royal Albert Hall, Music, Art and Drama Society concerts

First of three May concerts with the New London Orchestra, leader Max Salpeter

Conductor: Alec Sherman, Soloist: Elisabeth Schumann

Lovely concert. Elisabeth Schumann wonderful. We saw her afterwards and walked out behind her and watched her drive off in her car. She took at least half-dozen bows! Oscar played with the New London for this concert. They played the 'New World' very well indeed.

\section{Monday, 27 May}

Royal Albert Hall

Philharmonia Orchestra, leader Leonard Hirsch Schnabel, Dobrowen

This concert was absolutely perfect. Schnabel, of course, is a past master and the ease of his playing and his brilliance have to be heard 
to be believed. The Philharmonia are, I think, about the best English orchestra at present, though they are a new combination. Their 5 th Symphony was excellent, lots of variety of tone, and the conductor too was excellent. Altogether, a very fine concert. Oscar, by the way, played with the Philharmonia for this. $\mathrm{He}$ is free-lancing now, and not with the L.P.O. Don't you think this is a very handsome programme (in spite of the fact that I've spoiled it by writing in the margin!).

\section{Wednesday, 5 June}

\author{
Sir Thomas Beecham, BBC Chorus \\ (led by Leslie Woodgate), Marjorie Lawrence \\ Rossini, overture, 'La Gazza Ladra' \\ Berlioz, 'Chasse royale et orage (Les Troyens)' \\ Sibelius, Symphony 7 \\ Wagner, Tristan and Isolda, Prelude, \\ Isolda's narration, prelude to Act III, \\ Isolda's Liebestod.
}

This was a wonderful concert. Tommy superb as usual. He really is a genius. And Marjorie Lawrence has a grand voice - extremely powerful - just right for Wagnerian heroines. ${ }^{10}$

\section{Sunday, 9 June}

William III Orangery, Hampton Court Palace Third Series Serenade Concerts in association with the Arts Council of Great Britain

New London Orchestra, conductor Alec Sherman Jacques String Orchestra, conductor Dr Reginald Jacques

10 Note how she seems completely oblivious of Wagner's far from commendable views of Jews, expressed for example in his illinformed disdain of Mendelssohn. On this, see, for example, Sinéad Dempsey-Garratt, 'Mendelssohn's "Untergang": Reconsidering the impact of Wagner's "Judaism in Music"', in Mendelssohn's Perspectives, ed. N. Grimes and A. A. Mace, Farnham: Ashgate, 20I2, 3 I-48.
We went to the one on Sunday, 9th June (Leon Goosens). Oscar was playing. The weather was fine, and we had a lovely time. The music sounded lovely in the Orangery, which is a long narrow room. The orchestra sit in the middle and the audience on each side of them. It is queer, but rather nice and informal.

\section{Wednesday, 19 June}

Royal Albert Hall

BBC Symphony Orchestra, leader Paul Beard

Conductor: Sir Adrian Boult

I have just come home after the concert. I daren't profane this programme by writing on it. The concert itself wasn't too good. The BBC Symphony's strings were very bad. And their accompaniment to the Concerto was really dreadful. I've never heard worse. Anyway, I'll tell you all about it.

My friends and I usually go to the artist's room after the concert in case we can see the soloist. Usually (as we know the doorman) we do manage to. I've had some programmes autographed before, but usually they won't sign more than one each. Tonight, Szigeti (who had finished the Concerto looking furious and as if he would like to shoot Boult and the orchestra! - I would have liked to! -) was very nice and let everybody in, and signed all our programmes. And I had a long conversation with him!!!! I started by saying, 'Please, may I ask you a question?' He said, 'Yes, what is it?' I said, 'Did you think the orchestral accompaniment was good or not?' He looked at me then, and said, 'Well, Beethoven is capable of so many different interpretations - and I didn't alter my own standard, and the BBC Symphony have theirs ... perhaps they were a bit heavy.' I said 'I didn't think they were good at all.' And he said, 'Well, don't put me on the spot too much!' Then I said, 'By the way, was your $\mathrm{A}$ in tune with theirs?' $\mathrm{He}$ 
had been tuning all through and they never were quite in harmony. He looked at me and said, 'That was my fault, my A kept going flat.' Then he looked at me sharply, and said, 'Are you a violinist?' I said 'Yes' (!!) and he said 'Ah, well, you'll understand, it's a new string!' Then I asked him what his violin was, and he said Guarnerius, and showed it to me. Wasn't it nice of him to be so kind! And wasn't I cheeky! I don't know how I had the nerve to talk to him like that, but it's rather funny, isn't it! I am pleased!

\section{Sunday, 23 June}

\section{Harold Holt Sunday Concerts \\ London Symphony Orchestra (led by Lionel Bentley) \\ Conducted by Antal Dorati, Soloist: Yehudi Menuhin}

This was lovely. Yehi is superb and I do love the Brahms. Dorati is striking-looking and a good conductor. Yehi wouldn't sign any programmes, but if you look on the back page, you'll see Dorati's. He signed simply hundreds.

\section{Tuesday, 25 June}

Royal Albert Hall

National Symphony Orchestra

Mischa Elman

Conductor: Albert Coates

We had great fun at this concert. We were up in the balcony, right round on keyboard side, so when Mischa Elman came on to the platform, all we had was a lovely view of a bald head, like this:

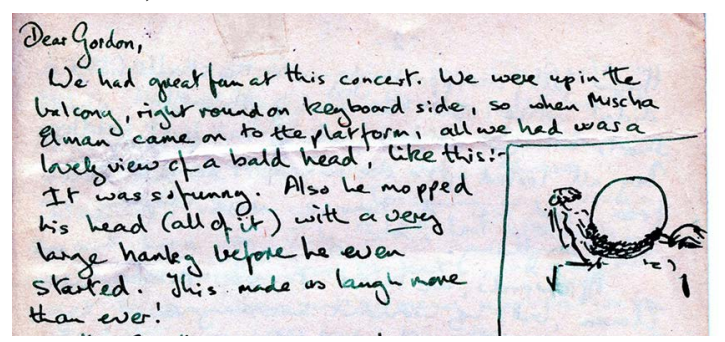

It was so funny. Also he mopped his head (all of it) with a very large hanky before he even started. This made us laugh more than ever!

His Beethoven was peculiar. First two movements spoilt by bad intonation and uneven tempo, but the third movement quite good. His Tschaik. was obviously his showpiece - the first movement was superb, and the rest very good. He was very pleased with himself, and played two encores - Air on the $\mathrm{G}$ string and some unaccompanied Bach. $\mathrm{He}$ knows what he can do. His tone on the $G$ and D is lovely, but once on to the A string and his intonation goes to pieces. Pity. It was funny! During the 'Air', he kept turning with a grin to the first fiddles as if to say 'Aren't I good!' He looked just like the funny little man who leads the band at Lyons Corner House. I had a rose on my coat, and so had another of the girls, and we decided for a lark we would throw them to him. The one my friend threw fell disappointingly into the stalls (they didn't notice) but the ones I threw fell short, but just at the feet of the first fiddles. They all looked up to see where it had come from, and we of course were laughing like anything.

Afterwards, we tried to see Mischa Elman, but he wouldn't see anyone. I recovered the roses from the stage, and then we saw Albert Coates, who was very nice and friendly, so I gave them to him, with a little speech. He said, 'Oh, how sweet' and told me to put them in his buttonhole which I did, greatly to everyone's amusement. It is as well he didn't know that they had already been thrown down from the Balcony! I also told him that one of the programmes he was signing was going out to you in India, and he said, 'Really?' and seemed quite impressed. Altogether, I had a very amusing evening. I love 'Capriccio Espagnole' don't you! I've had, really, a surfeit of music lately - 5 concerts (including radio ones) in 6 days! On Monday 


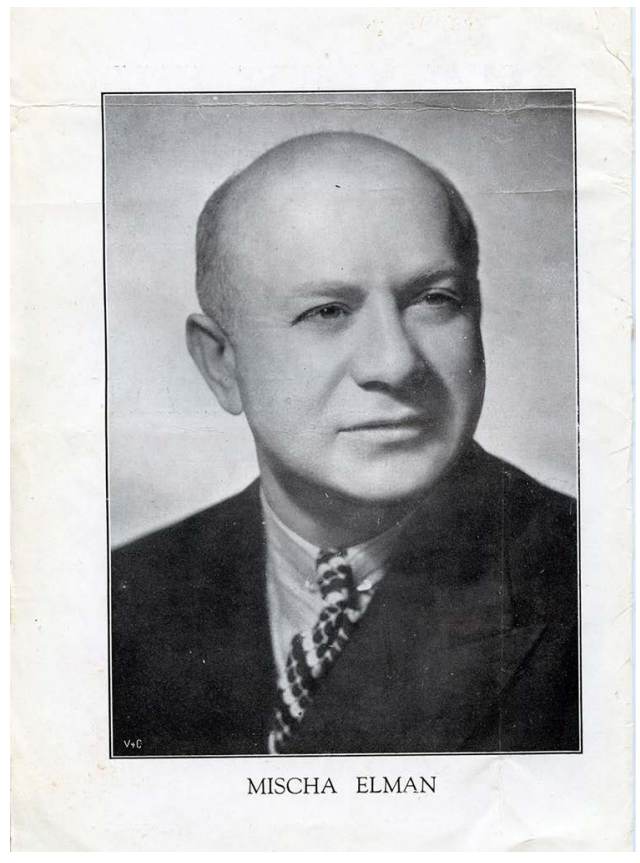

night there was a broadcast of Toscanini from La Scala in Milan. They played Beethoven's Ist and 9th Symphonies. Both simply glorious, especially the 9 th. What voices those Italians have. Toscanini is giving a concert here on July 3 rd, but although we have written for tickets, we may not get them. There are so many applications that they are balloting for them. That's all for now. I must go and practise.

\section{Sunday, 30 June}

\section{Harold Holt Sunday Concerts London Symphony Orchestra (led by George Stratton), conducted by Antal Dorati}

This was a lovely concert. I also went to the rehearsal in the morning (we asked Dorati last week at the Menuhin concert). He is a very good conductor, especially in music like the Galanta dances. Have you ever heard this suite of dances by Kodály? At the moment, I can't think of anything else. I simply love them. The entry of the first violins is one of the most emotional things I've ever heard
- makes me "melt" inside. When I wrote to you last, after reading "Humming-Bird" again, I was feeling all I 8th-century, wasn't I? Well, tonight, I feel wild and gay and it's all the fault of that gipsy-music. Oh, it is marvellous. The L.S.O. played remarkably well, except for the horns, who ruined part of the Tschaik. 5 th. Otherwise, very good performance indeed.

\section{Saturday, 6 July}

\section{Cambridge Theatre}

M.A.D. Society Season of Opera and Ballet New Monte Carlo Ballet with Serge Lifar, directed by Eugene Grunberg, Conductor Eugene Bozza

I went with Oscar's little girl, Irma, to see this. He was playing. It was very, very modern but interesting. The music by Tcherepnina was the nicest.

\section{Why did things peter out?}

Poring over Doris's letters, I was fascinated, but also saddened that this promising relationship had petered out. My father did meet Doris after his return from India, in a Lyons' Corner House near her place of work, ${ }^{11}$ and he also visited her briefly at home, where he remembers her parents; her father, in particular, was taciturn (he assumed, wrongly, that he was not conversant in English). Frustratingly,

11 The venue in question was probably the Oxford Corner House on Tottenham Court Road. Lyons' Corner Houses and smaller Lyons' tea houses were a wellknown part of the fabric of society at the time; the last of them closed in $\mathrm{I} 98 \mathrm{I}$. The company was of Jewish foundation and management: the tobacco merchants Isidore and Montague Gluckstein and Barnett Salmon appointed Joseph Lyons to run their new venture, founded in 1887 , under his name. 
he simply does not remember how his personal encounters with Doris actually went, beyond the fact that they were friendly and he retained his admiration of her achievements.

Despite my attempts at probing, he was also at a loss to explain why the correspondence and friendship came to an end, and Doris herself appears to have left behind nothing she may have recorded about it. Whatever the reason, we may well surmise that she must have been disappointed that the correspondence did not lead on to a more lasting musical friendship and encouragement of her own endeavours.

\section{'Tell me where is beauty bred'}

One of the puzzles with Doris is how, given her background, she managed to rise to the level of cultural acumen that is evident in her letters. She indicates her lowly background herself, and the lack of support for cultural endeavour on her father's part. ${ }^{12}$ Nowhere, however, does she seem to regard her cultural aspirations as in any way exceptional. The family was of humble origin on both her parents' sides, and they lived a modest and frugal life in East London. They were unexceptional, Orthodox Jews, not specially religious or assiduous observers of kosher rules (AL, DH-G). ${ }^{13}$ As far as we can determine,

12 Her father was Abraham Jacob Bresh ('Jack'), a tailor, who was born in I 900 and died in 1978, and her mother Annie, née Levene, born 3 I May I 889 (according to her passport), died I 976 in Israel; they married in 1925 .

13 We could not confirm anything about their synagogue attendance, but the nearest synagogue to Doris at the time of the correpondence was the Clapton Federation Synagogue (Sha'are Shamayim), a rare art deco masterpiece by Marcus Kenneth Glass from I 93 I-2; the building was nefariously destroyed in 2006 as locals tried

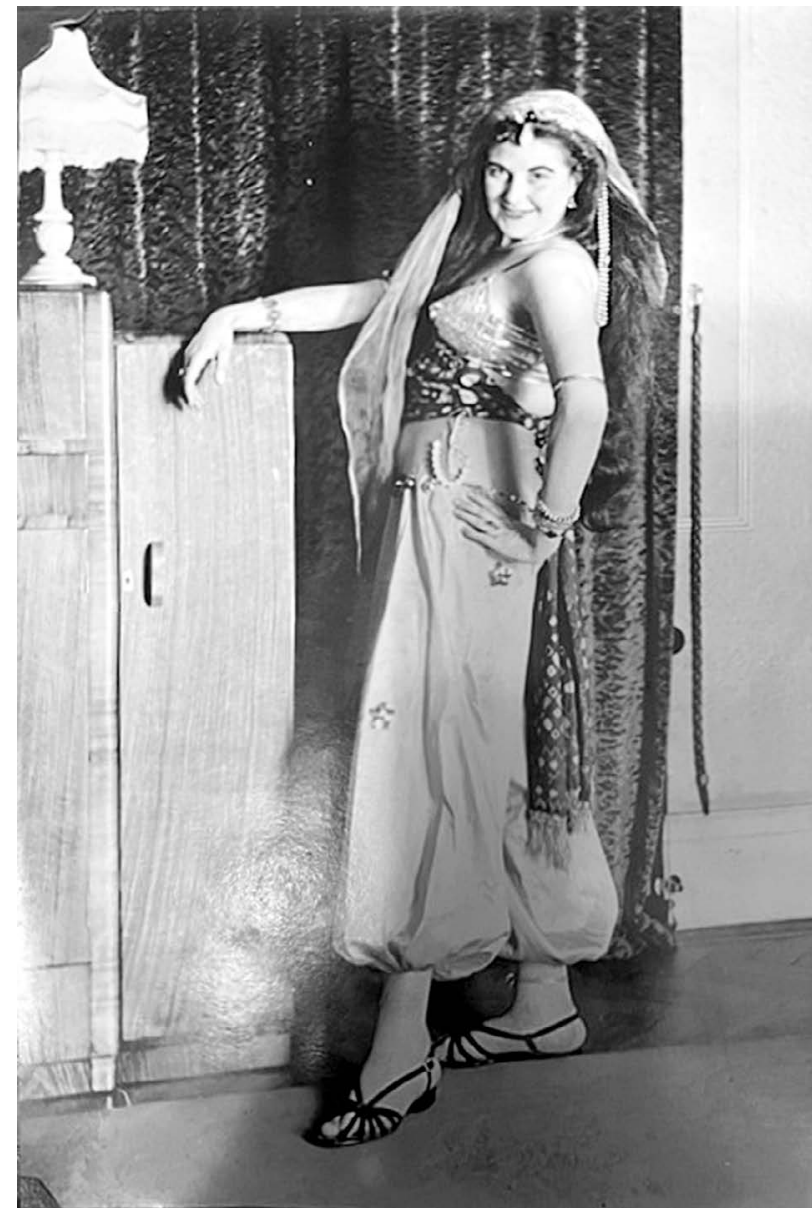

Doris performs at the Chelsea Arts Society ball, 31 December 1952.

they did not engage in a great deal of cultural activity outside their mundane existence (AL); Annette noted how unusual it was for a Jewish girl from this limited background to develop the cultural interests and skills that Doris possessed.

Doris's support came from her mother, who also made sure the family made sacrifices to ensure a good education for her at a leading local school, the Central Foundation Girls' School. We may suppose that the

to get it listed as a national monument: see $<$ http://jewishheritage.org.uk/sites-at-risk/ demolished $>$. 


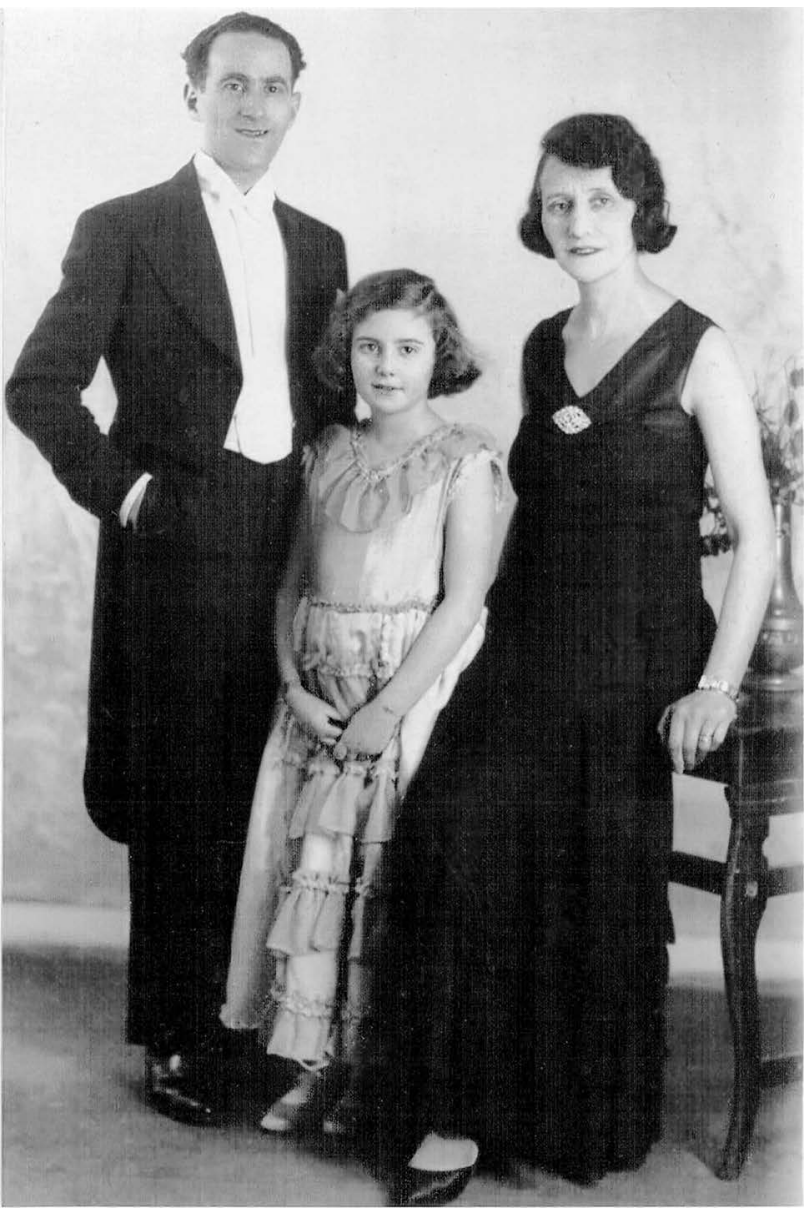

Doris with her parents soon after her eighth birthday.

school offered a broader cultural experience than her family background could offer, and her interest in concert-going seems to have stemmed in part from such outings from school (DH-G). Her interests in any case started at an early age: she was keen to learn the violin from the age of eight (DB). Nonetheless, Doris's humble origins make the natural poise and command of the cultural scene of classical music that she displays in the letters remarkable; a great deal must have come simply from within herself and her determination to succeed, something that emerges, in a self-effacing way, in her letters, as she fearlessly quizzed all the leading performers of the day, and endeared herself to members of the great London Philharmonic Orchestra, securing herself lessons and a fine instrument.

Yet how exceptional was Doris? With our perceptions moulded by the modern world, we may be being dazzled by something that did not seem that notable at the time; this raises some fascinating questions about our perception of the past, and the supposed achievements of modernity. I am no expert in the area, to be sure, but a few observations may be worth making.

Whilst nowadays they would have completed their schooling and gone on to university, there was no possibility for children of humble families, such as my father or Doris, to do other than leave school at around age I $_{5}$ (the age for the end of compulsory education). ${ }^{14}$ Girls in particular at this period were under great pressure not to 'waste time' staying on at school. We may decry the lack of opportunity: yet the effect was that there was a large pool of people whose lack of formal education was due to poverty (and gender), rather than inability. Hence, the working classes were full of people with the talent and motivation to succeed in careers and cultural activities, without such regard to their educational or social achievements as is the norm these days.

There was, then - to take a somewhat contrarian point of view - arguably far less expectation of polarisation along class lines in career and cultural terms than there is

14 By way of parallel, my mother, too, who was desperate to carry on at school, was forced to leave at this age and start earning for the family - but, like Doris, she managed to pursue her cultural interests, reading widely (in particular the works of the Brontë sisters) and eventually qualifying as an English teacher (as a woman, she had had to resign from her position in the civil service upon marriage). 
nowadays in Britain. ${ }^{15}$ In many ways, society was more cohesive than in modern Britain, and the result of the pool of gifted but formally under-educated people was also that there was nothing particularly odd in being of humble origin yet fascinated by 'high-brow' culture like classical music (GT strongly confirms this as his perception of the times). And while formal education was closed off to many such people, there was a plethora of less formal avenues to pursue, particularly in the form of state-supported evening classes and activities such as amateur orchestras. My father often decries how these once plentiful and thriving activities, often supported by local government, which he took part in with some alacrity, disappeared over the years. High-brow culture feels a good deal more elitist now than it seems to have been felt to be in 1946 .

The past really is a different place, then and not altogether a worse one. I would not wish to downplay Doris's exceptional talents, given her background, but I think nonetheless that they need placing in their more culturally enlightened context. ${ }^{16}$

15 Since writing this, I see that a similar point is made (no doubt one among many) in a perceptively scathing political analysis by Polly Toynbee in The Guardian (I 3 April 202I), <https://www.theguardian.com/ commentisfree/202 I/apr/I3/elizabethanera-britain-reign-tory-party>.

16 As for my father, he never managed to secure a position in an instrument workshop, though he was perhaps too picky (the job at Boosey \& Hawkes that Doris mentions, for example, he turned down, as he was to be apprenticed to a doublebass maker instead of a violin maker). $\mathrm{He}$ attended evening classes in violin making, but pursued it no further (I still have some of his tools, however). He did play for many years in an amateur orchestra, using a fine Cremona-made modern violin that my mother bought for him in 1954 .

\section{Seeking Doris}

Whatever the reason for its demise, I felt a great sadness that my father had failed to develop such a promising friendship. Yet he had passed the letters on to me, and it felt as if a responsibility came with them. I wondered: he was ninety-six; she would be five years or so younger. Could she still be alive? Could I find someone from three-quarters of a century ago? It would be fascinating to talk to her. I am a researcher, and felt compelled to try - although my expertise is very definitely not in Jewish family-history research. I had only the name and her address, and her year of birth, to go on. A search on Google revealed very little.

I careered down many other avenues. I worked out which synagogue she must have gone to and contacted them. A very helpful lady replied, saying that unfortunately there was just no-one left old enough to remember back that far, and they otherwise had no records. I checked the Jewish Chronicle (I was lucky enough to do this shortly before they started charging for access to the archive), and I found several references to Doris, revealing the active young woman that was already known to me in a different sphere from the letters. The last mention was of her as a runner-up in the national Perfect Secretary awards from I953, which gave me a little more information. But then nothing. She would have married, of course: but I could find no record of that. I registered with a Jewish genealogical site. The problem here was that there were many Doris Breshes (mainly in America). I managed to gradually narrow the search down, yet still I did not find much. I wrote to one possible relative, but received no reply. Things were looking hopeless.

Doris seemed to be so much part of English life that I imagined she must have 
PERFECT SECRETARY CONTEST

Jewish Girl in Final

In compation for Britatis Perlect

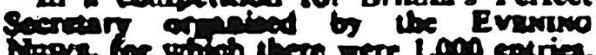

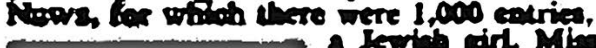

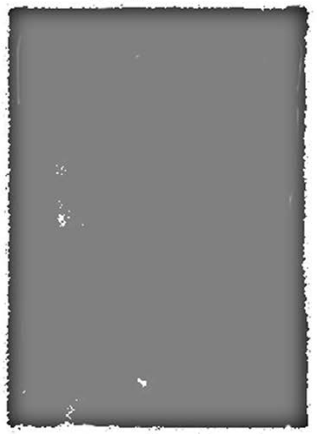

Mlse D. sone
Doris ines. and

27. of Int.ituratic

Nond ES, wh enons the eidit fintists $\mathrm{Ine}$ nin. net ens Mirs Jeanctle Janvisa of Hanpoutead. Mise Bresh. who, lor the ons two vears has beet serving ro Mr. Max Director of the J.N.F. was formerly "P i ivaie seretiary io Mr. James A. de Rothectrild and the bite Sir Fiarold tutter, Chairman of the Economic Leaque for European Co-operation, Don- overnmentil voluotary committes.

At ive end of the war Mies Bresb was - Aceretary in the ofitices of the Cabinet. and left with a letler of thanks for her cervices theod by the Prime Minister and Lord Lemay. Miss Bresh is troenly insereated in music and is a viotiniz with the Ben Uri Ordiestra.

Doris appears in The Jewish Chronicle, 2 May 1953.

stayed here. Yet in the end I figured she must have emigrated. I tried the Englishspeaking world first - particularly Australia and America. Nothing. Israel was the obvious answer: but I cannot read Hebrew, and any attempt to establish information about migration there proved fruitless with my resources. Finally, after a week's work, I came across the Farhi family tree site, Les Fleurs d'Orient, which aspires to include all Sephardic Jews. Doris would have been Ashkenazy, of course, but could have married into a Sephardic line. And there she was: married to David Hasson - the information having been originally uploaded by Doris's daughter Dalia, who is of Farhi descent on her father's side. There was no contact information, but he was listed as professor at Technion-Israel Institute of
Technology. I checked the institute's website, and sent an email. I got a swift reply confirming my conclusions, and Prof. Hasson also phoned me and was delighted to talk about the family. The sad news, though, was that Doris had passed away just three years before (within days of my own mother, it turned out), in the spring of 2014 , so we could not renew the acquaintance from so long ago. Doris's daughter Dalia, however, who is much the same age as myself, has offered a great deal of support in putting together some reflections on her mother. I have also been assisted by Doris's paternal cousin, Annette Lewis.

\section{The move to Israel}

Annette recalls that it was a great surprise when they heard that Doris had moved to Israel in the early I95 os, leaving her family network in England behind. Although she does not mention it in the letters, Doris was scarred by the experience of growing up in the Blitz (DH-G), and relations with her father were cool (as is already gently intimated in the correspondence). Such experiences surely formed the background to her thoughts of leaving the country. Doris's mother, with whom she was close, joined her in Israel some years later.

Doris in fact scarcely spoke of her motivations for emigrating; in so far as she said anything, she merely quipped that she had 'followed the sun to Israel', echoing the government propaganda slogan of the time (DH-G). A motivation of this sort may seem slightly facile to us today, but we need to recall the very different world of post-war Britain. To illustrate this, it seems fitting to quote a few passages written by children from the school magazine of Doris's school, the Central Foundation Girls' School, situated near the heavily bombed East End of London, from the February I 946 issue (VI.I): 
Do my eyes deceive me?

One morning I came down to breakfast feeling extra happy. Suddenly my eyes were glued to something on the table. It was like a small full moon and its pale yellow skin was shining in the sunlight which streamed in through the window. It seemed to grow larger and larger until it filled the whole room, and then it shrank back to its normal size again and I sat down to breakfast. My Mother told me she had queued for two hours for that one and some more like it, and later, when I ate a half of it I thought 'What a lovely thing is a grapefruit!'

J. Popkin, Lower IVa

The next piece, by G. Bottone, is entitled 'The Little Yellow God', and begins 'Banana, $\mathrm{O}$ Banana, Why don't you come to me?' It is a heart-felt plea for an abundance of the longabsent fruit now the war is over. On a different topic, Audrey Phillips (old girl) writes:
How shabby London is looking! Throughout the war its increasing shabbiness went unnoticed, the mere fact that a street was untouched by bombs was something at which to wonder. Now the constant threat of destruction no longer dulls our appreciation of the niceties of life, the dust of the ruins seems to cloud the air and obliterate the faint touches of colour still left.

On top of the absence of nourishing food - within a strict rationing system that lasted for many years after the war - and the shabbiness of a bombed-out, dusty, derelict capital city, there were the infamous 'pea-soupers', noxious, pollution-laden soot-filled fogs. The Clean Air Act did not come into force until I 956 .

The appeal of a warm, mediterranean land may thus have been strong - and she also had it in mind to find a Jewish husband (DH-G). When she finally migrated, she did so in the

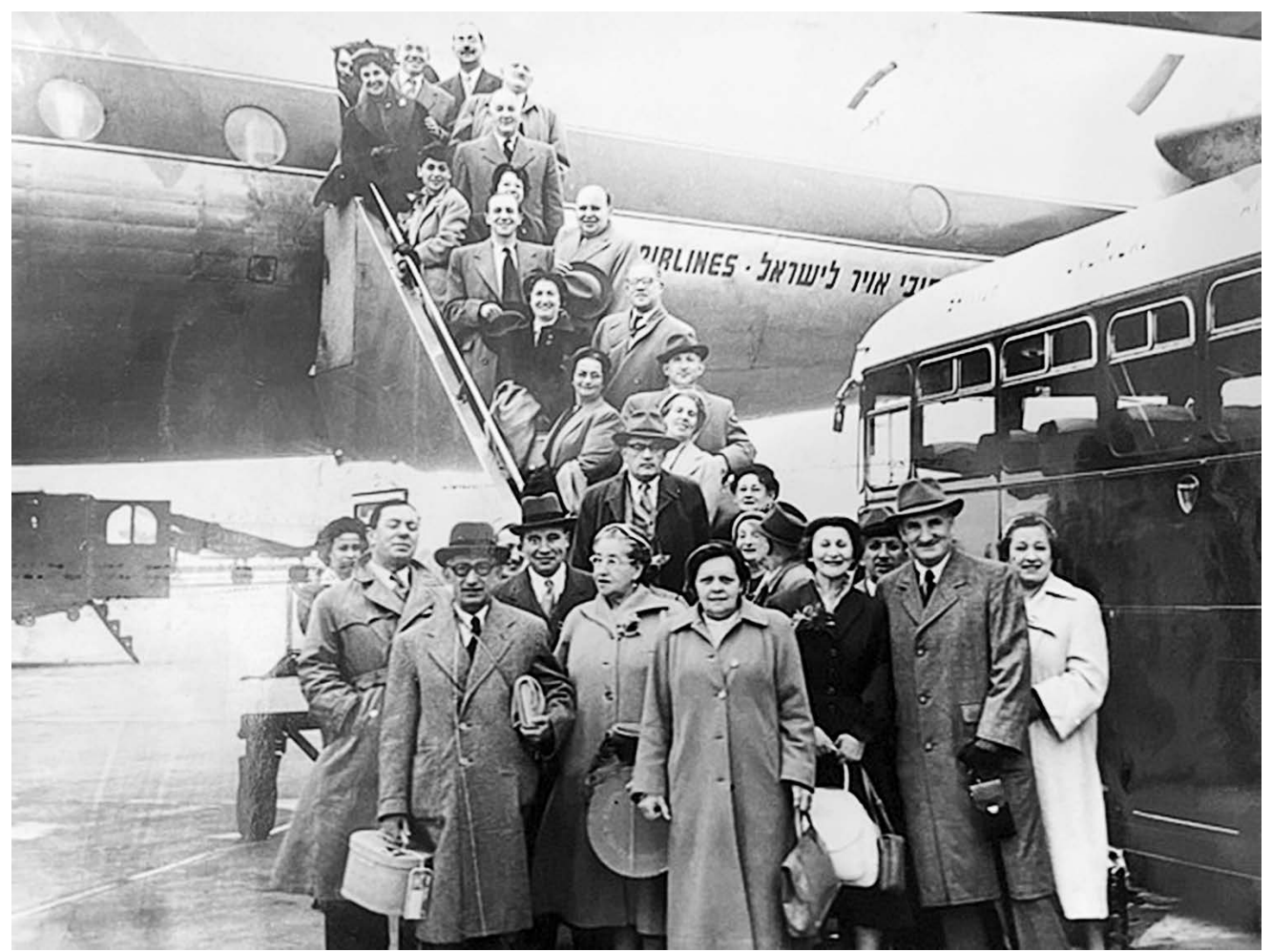

Doris (top left of stairway) arrives in Israel; this undated photo is likely to mark her migration. 
company of a small group of her close female friends.

Yet a look at Doris's career reveals deeper reasons for her move.

In 1946, she was delighted to be working in a musical instrument firm, as her letters to my father spell out. For some reason that cannot now be determined, she gave up this position. She hints in her correspondence, indeed, that she could easily secure a better secretarial position elsewhere; she had, after all, been secretary in the Cabinet Office and received a commendatory letter at her departure from Winston Churchill and Lord Ismay (JC 2.5.1953). The lure must in the end have proved irresistible. She obtained a position as private secretary to James A. de Rothschild. He was both a liberal politician and a strong Zionist and supporter of the establishment of the state of Israel. An unanswerable but intriguing question is whether Doris's attention had already turned to Israel, and possible migration thither, when she took up this position, or whether working for de Rothschild focused her thoughts in that direction.

Her next post was as private secretary to Harold Butler, chairman of the Economic League for European Cooperation, a sort of precursor of the European Union. This position appears fitting for someone with the open-minded, liberal aspirations that Doris expresses in her letters, where she rails against fascism and calls for cooperation between people and nations.

Her next secretarial post, from I95 I, was as assistant to the director of the Jewish National Fund in London, Max Weiner, in which role she continued for at least two years. The JNF, of course, sought to buy land in Palestine for Jews to settle. With the establishment of Israel in 1948, the government began a controversial process of selling land to the JNF, and in I953, the organisation was dissolved and re-established as a

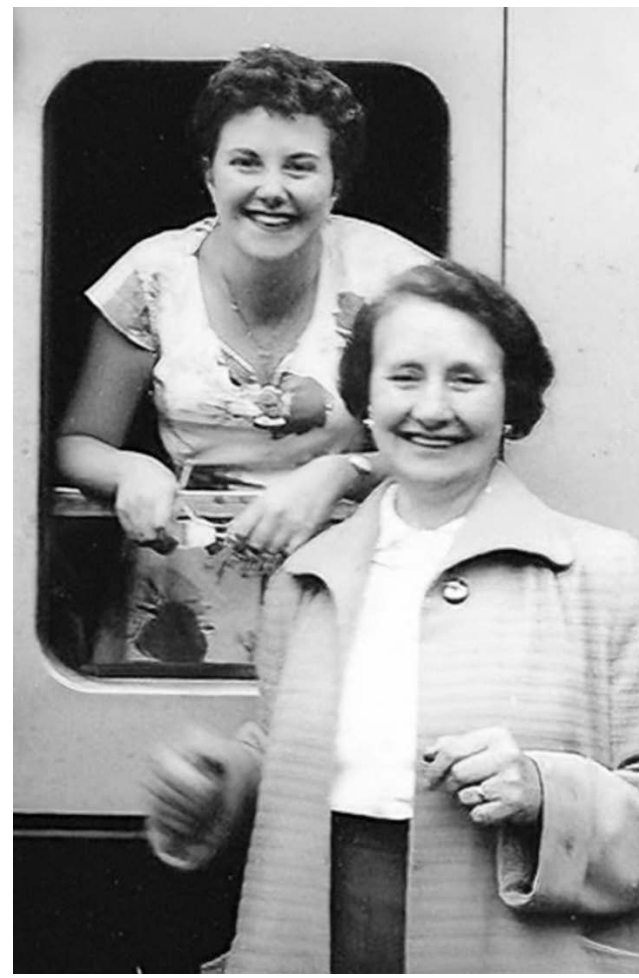

Doris (with her mother) sets off on a plane, possibly on her first visit to Israel.

private company, Keren Kayemet LeYisrael. It must have been at around this point that she arranged to emigrate to Israel. Doris's work at the JNF must surely have strengthened her resolve to migrate, particularly after she paid a visit to Israel in the course of her work (DH-G).

The decision to emigrate was certainly not motivated by lack of success in England, as her senior secretarial positions show. She was even a runner-up in the Britain's Perfect Secretary contest run by the Evening News in 1953 (JC 2.5.1953), as well as runner-up in the Miss Anglo-Jewry contest in $195^{2}$ (JC 8.2.1952). Her musical interests did not abate while in England: in I953, she was a player in the Ben Uri Orchestra (JC 2.5.1953). The correspondence with my father indicates a lively engagement in concert life, and she also made an impression in amateur drama 
(JC 5.II.I943 notes her outstanding performance). There is little doubt she could well have continued to lead a fulfilling life in Britain.

Doris appears to have made something of a break with the past once she moved. ${ }^{17}$ She did, however, continue playing the violin for a few years in the Technion Orchestra (DH-G's aunt), but eventually sold her precious instrument (DH-G). ${ }^{18}$ Thereafter, she does not appear to have maintained her musical interests in her new homeland, though she always remembered the London Philharmonic Orchestra with affection (DH).

On the other hand, more prosaically, Doris came to suffer from a debilitating illness after the birth of her second child (DH-G), and her abandonment of her musical and other pursuits may simply be a reflection of this, and of her responsibilities as a new mother.

It would be fascinating to know Doris's views of the developing state of Israel, especially given her role in the JNF - but alas, she seems to have left no record or comment on this part of her life.

In her new homeland, Doris met David Hasson - who was himself an amateur violinist from a musical family. ${ }^{19} \mathrm{He}$ had completed his doctorate at Imperial College, London, and then joined the Department of Chemical Engineering of Technion-Israel Institute for

17 Thus, no papers from before her migration survived, and she did not speak of that period of her life with her daughter (DH-G).

18 Her cousin Annette finds this astonishing, given her devotion to the instrument while in England; indeed, Annette's mother had a notion that Doris had gone to Israel in order to further her violin-playing (AL).

19 David's brother Reuben was a gifted violinist, and his sister Claire an opera singer; she established a scholarship in her and Reuben's name at the Jerusalem Academy of Music and Dance.
Technology in Haifa. They married in $195^{8}$, and had two children, Dalia and Daniel.

Doris passed away in 20I4 on the same date in the calendar as her mother some thirty-eight years earlier according to both solar (7 May) and lunar (7 Iyar) reckonings. During the course of investigating her papers to help with the present article, the family came across a wish she had recorded to have carved on her gravestone the moving words that the most renowned of English-language Welsh poets, Dylan Thomas, had composed for his own dying father (but she changed Thomas's 'rage' to 'fight'):

Do not go gentle into that good night Fight, fight, against the dying of the light

These words seem a fitting epitaph for the lively and determined woman who emerges from the correspondence that survived from I946.

\section{The aliyah in a wider perspective}

The move to Israel clearly marks a hugely significant turn in Doris's life, but we might also view it from a wider perspective, as exemplifying the aliyah of the Jews of the diaspora to the longed-for homeland. Doris's family's story begins in the Pale of Settlement, the area of Russia within which Jews were confined. Increasing restrictions, and indeed persecution, led many Jews to emigrate in the late nineteenth century and early twentieth, often to America, but also to Western Europe. Doris's father's father, Moishe (anglicised as Morris), 20 was given permission on I9

20 He was born on 26 July I 867 , and died in the Stepney district of London on I 3 February 1947. His name is recorded as Moishe Laib Lazerovich Briss on the departure permit, but his death record indi- 


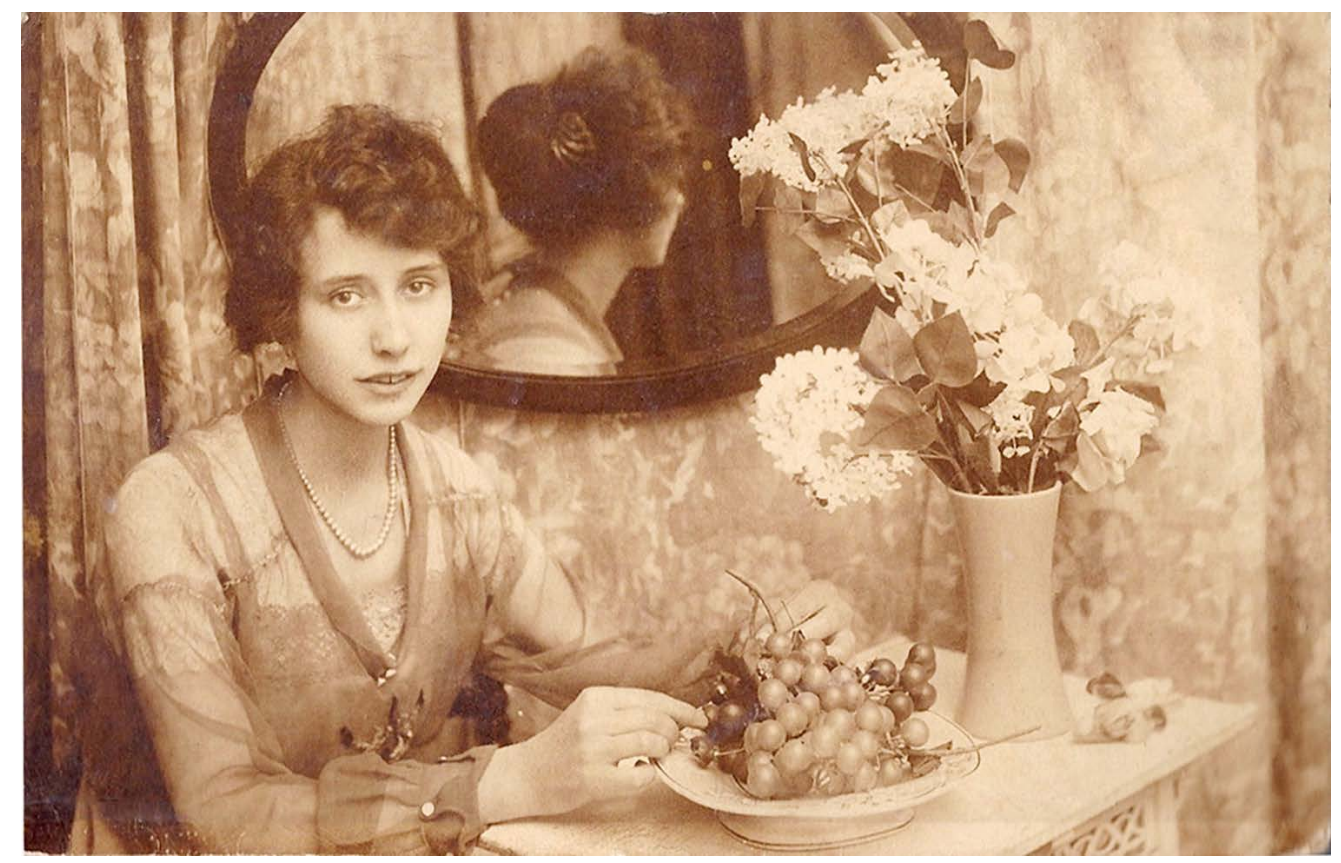

Doris's mother, Annie Levene, as a young woman.

November I 9 I to leave the Russian administrative district of Petrokovskir (now the Polish city of Piotrków Trybunalski, to the south of Łódź), where some I 2 per cent of the population was Jewish (permit held by AL). Doris's mother Annie Levene was brought as a baby around $\mathrm{r} 890$ from Vilnius (now in Lithuania), another area of the Pale with a high level of Jewish settlement (DH-G).

The aliyah, viewed as a multi-generational act, began in Russia for many Jewish families, of course. Doris's immediate forebears were, we might say, fortunate that their family passage was initially to Great Britain; their counterparts on the Continent had to confront the horrors of the Holocaust - I have not found any immediate connection with the events on

cates the form of the surname in Britain as Bresh. His wife Mary (Yedlisky), born ${ }_{24}$ December I 87I, died on 30 December 1944. They had seven children, six of whom came to England with them (the last being born after their arrival). (AL) the Continent in the Bresh family. ${ }^{21}$ Hence, in a sense, there is nothing in the history of the family that stands out from the mundane, nothing to compare with the investigations into the tragedies faced by so many other Jewish families. Yet this mundanity too is surely something to remember within the context of modern Jewish history over all indeed, it is something to celebrate, for we see in Doris an example of a mid-twentieth-century Jew who did not - as far as we can tell suffer for her Jewishness, and lived a 'normal', fulfilling life. At the same time, she took part in the aliyab to the new state of Israel, and so is part of the greater Jewish story.

Each oleb or olab has his or her own story to tell, however: and part of Doris's story, something that made Doris who she was as

21 Nonetheless, as Doris's grandfather had come to England from what is now Poland a mere thirty-five years before the correspondence, it is possible that she was aware of more distant relatives who had remained behind. 
a young woman, is the existence and exercise of her musical talent. There is nothing specially Jewish in this, and a reader could not tell from the letters that she was Jewish at all (apart from her name); but this too is the point. Her life story shows that her Jewish identity was important to her, yet as a young woman she was also fully a member of the society in which she grew up - indeed, she was able to wring out all the goodness, in cultural and career terms, that the wracked world of post-war Britain had to offer. I would like, through this article, to celebrate the paradox of her being simultaneously quite unexceptional and quite exceptional.

\section{Final thoughts}

Doris conjures up before our eyes the astonishing vibrance and exuberance of cultural life that was on offer in a ravaged London so soon after the war, and it is equally moving to see the support it received from ordinary people, young shop and company workers like her. Her acute observations offer some finely drawn glimpses of the leading musicians of the time, and of the life and enthusiasm of an amateur violinist who engaged with them.

We live in a different world today; one of the sobering aspects of the investigation into the context of the letters and my father's memories of those times was to come face to face with just how much has changed - and by no means all of it for the better - within his lifetime, and this in turn has afforded a certain sympathy with the bewilderment sometimes felt by his generation at trying to understand or accept the realities of the modern world. 22

22 The gulf between the world of his boyhood and ours of today was brought home when, some years ago, we visited the Somerset village of Dean, where his family came from, and to which he returned for occasional
Yet Rachmaninov, Mozart, Sibelius were there, in that world of yesteryear, and they are with us still. So too, we may hope, are men and women, be they Jewish or not, who, like Doris as she was then, are keen to seize the day, to reap the joys and rewards that are the guerdon of those who accept the challenge of cultural endeavour in a world still wracked by ills, different as they may be from those of 1946 .

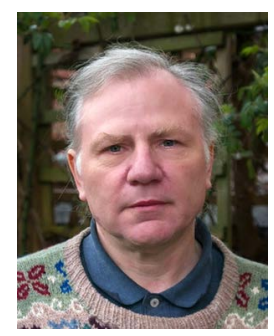

Clive Tolley took his D.Phil. at Oxford University in 1993. He is a docent of the University of Turku, specialising in pre-Christian Norse and Finno-Ugric myth and religion and Siberian shamanism. He is an academic editor and typesetter, and carries out English-language checking for NJ/SJS. He once taught for a year in the Orthodox Jewish Pardes House school in London. He has an Open University Diploma in Music, and plays the viola da gamba and violin (not very well). He lives mainly in Chester, England.

\section{Informants}

I would like to thank Doris's family for their unstinting support and the provision of information and photographs.

DH Prof. David Hasson (husband of Doris)

DH-G Dr Dalia Hasson-Gilad (daughter of Doris; sometimes relaying information from other, older members of the wider family)

AL Annette Lewis (paternal cousin of Doris)

GT (Clement) Gordon Tolley (Doris's correspondent; my father)

stays from Belgium. We had great difficulty in crossing the busy and dangerous $\mathrm{A}_{3} 6$ I (the widening of which in the r 970 os resulted in the demolition of his family's cottage); he related that as a boy, he would walk for hours along the road towards the nearest town with his sisters, wagering whether they would see a car that day or not. 


\section{Sources}

CFGS: Central Foundation Girls' School magazine: some are available at <https:// www.central.towerhamlets.sch.uk/page/?titl $\mathrm{e}=\mathrm{CFGS}+$ Historical + Archive + Resources\&p id $=26>$.

DB: Doris Bresh, letters to Gordon Tolley, 1946 (private archive).

FO: Les Fleurs d'Orient, the Farhi genealogical website of Sephardic Jews, <https://www. farhi.org/genealogy/index.html>.

JC: Jewish Chronicle newspaper (paywall) at $<$ https://www.thejc.com/archive>.

The Strad, magazine for (bowed) stringedinstrument players and makers (no accessible online archive). 